\title{
The FlbA-regulated predicted transcription factor Fum21 of Aspergillus niger is involved in fumonisin production
}

\author{
David Aerts • Esther E. Hauer • Robin A. Ohm • Mark Arentshorst • \\ Wieke R. Teertstra $\cdot$ Christopher Phippen $\cdot$ Arthur F. J. Ram • Jens C. Frisvad • \\ Han A. B. Wösten
}

Received: 1 June 2017/ Accepted: 25 September 2017/Published online: 30 September 2017

(C) The Author(s) 2017. This article is an open access publication

\begin{abstract}
Aspergillus niger secretes proteins throughout the colony except for the zone that forms asexual spores called conidia. Inactivation of $f l b A$ that encodes a regulator of G-protein signaling results in colonies that are unable to reproduce asexually and that secrete proteins throughout the mycelium. In addition, the $\triangle f b A$ strain shows cell lysis and has thinner cell walls. Expression analysis showed that 38 predicted transcription factor genes are differentially expressed in strain $\triangle f b A$. Here, the most downregulated predicted transcription factor gene, called fum 21, was inactivated. Growth, conidiation, and protein secretion were not affected in strain $\Delta f u m 21$.
\end{abstract}

Electronic supplementary material The online version of this article (doi:10.1007/s10482-017-0952-1) contains supplementary material, which is available to authorized users.

D. Aerts - E. E. Hauer - R. A. Ohm .

W. R. Teertstra · H. A. B. Wösten ( $\square)$

Microbiology, Department of Biology, Utrecht

University, Padualaan 8, $3584 \mathrm{CH}$ Utrecht, The

Netherlands

e-mail: h.a.b.wosten@uu.nl

D. Aerts

e-mail: d.aerts@uu.nl

E. E. Hauer

e-mail: e.e.hauer@students.uu.nl

R. A. Ohm

e-mail: r.a.ohm@uu.nl

W. R. Teertstra

e-mail: w.r.teertstra@uu.nl
Whole genome expression analysis revealed that 63 and 11 genes were down- and up-regulated in $\Delta$ fum 21 , respectively, when compared to the wild-type strain. Notably, 24 genes predicted to be involved in secondary metabolism were down-regulated in $\Delta$ fum 21 , including 10 out of 12 genes of the fumonisin cluster. This was accompanied by absence of fumonisin production in the deletion strain and a $25 \%$ reduction in production of pyranonigrin A. Together, these results link FlbA-mediated sporulation-inhibited secretion with mycotoxin production.

Keywords Asexual development - Aspergillus · Fumonisin · Fungus · Mycotoxin · Secondary metabolism $\cdot$ Protein secretion

\footnotetext{
M. Arentshorst · A. F. J. Ram

Department of Molecular Microbiology and

Biotechnology, Institute of Biology Leiden, Leiden

University, Sylviusweg 72, 2333 BE Leiden, The

Netherlands

e-mail: m.arentshorst@biology.leidenuniv.nl

A. F. J. Ram

e-mail: a.f.j.ram@biology.leidenuniv.nl

C. Phippen · J. C. Frisvad

Department of Systems Biology, Technical University of

Denmark, 2800 Lyngby, Denmark

e-mail: cbwp@bio.dtu.dk

J. C. Frisvad

e-mail: jcf@bio.dtu.dk
} 


\section{Introduction}

The genus Aspergillus consists of more than 300 species (Samson et al. 2014) that are among the most abundant fungi on the globe. Aspergilli degrade plant waste and as such play a role in carbon cycling in nature. Moreover, the genus includes opportunistic pathogens of plants, animals, and humans (Krijgsheld et al. 2013a). Enzymes secreted by Aspergillus play an important role in degradation of organic material and pathogenicity. The property to secrete high levels and a diversity of enzymes make aspergilli such as Aspergillus niger important cell factories for the production of proteins and metabolites (Meyer et al. 2011; Wösten et al. 2013).

Aspergilli form a mycelium consisting of a network of hyphae that grow at their apex and that branch subapically. The mycelium grows initially vegetative but at a certain moment asexual development is initiated (Krijgsheld et al. 2013a). The resulting conidia are the only spore type that are produced by A. niger. Conidiation starts with the formation of thick aerial hyphae called stalks. When a stalk has reached a certain height, its tip swells to form a vesicle. In many aspergilli, this structure buds resulting in a layer of metulae. The metulae in turn form a layer of phialides, from which chains of conidia develop. These spores are heterogeneous in composition, water dispersal efficiency, and germination rate (Teertstra et al. 2017) and give rise to new mycelia.

The zone forming the asexual conidia within an $A$. niger colony does not secrete proteins, while nonsporulating zones do release proteins into their environment (Krijgsheld et al. 2013b). Preventing conidiation of the colony by covering it with a polycarbonate membrane does not impact the spatial secretion pattern indicating that the capacity to sporulate but not the conidiation process itself inhibits secretion. FlbA was shown to impact spatial secretion in the colony (Krijgsheld et al. 2013b). This protein regulates the $\mathrm{G} \alpha$ subunit FadA by activating its GTPase activity. By doing so, it promotes asexual development and inhibits vegetative growth and autolysis (Wieser et al. 1994; Yu et al. 1996). Conidiation is abolished in the $\triangle f b A$ strain of $A$. niger and, as a consequence, protein secretion takes place throughout the colony (Krijgsheld et al. 2013b). Moreover, the cell wall of $\triangle f b A$ is thinner and intracellular proteins can be found in the culture medium, indicative of cell lysis. The $\triangle f l b A$ strain therefore has a pleiotropic phenotype. Inactivation of $f b A$ is accompanied by differential expression of 38 transcription factor genes, of which 18 are down-regulated and 20 are up-regulated (Krijgsheld and Wösten 2013). These downstream regulatory genes may impact one or more of the processes affected by FlbA. Here, the role of the most down-regulated predicted transcription factor gene, fum 21, was studied. It is shown that fum 21 regulates production of the mycotoxins fumonisins. Thus, sporulation-inhibited protein secretion is linked to production of secondary metabolites via FlbA.

\section{Materials and methods}

Strains and culture conditions

A. niger strain MA234.1 (transient ku70::amdS) (Park et al. 2016) and its derivatives were grown at $30{ }^{\circ} \mathrm{C}$ using minimal medium (MM) (de Vries et al. 2004) containing $25 \mathrm{mM}$ xylose as a carbon source and either (MM-XA) or not (MM-X) containing 1.5\% agar. Alternatively, strains were grown on Czapek Yeast Auto-lysate (CYA) agar (Frisvad and Samson 2004), Yeast Extract Sucrose (YES) agar (Frisvad and Samson 2004), or transformation medium (TM; MM containing $0.5 \%$ yeast extract, $0.2 \%$ casaminoacids, and $25 \mathrm{mM}$ glucose, $\mathrm{pH}$ 6)(Kusters-van Someren et al. 1991).

Conidia were harvested from 3-day-old MM-XA cultures. Liquid cultures inoculated with $5 \times 10^{8}$ spores were pre-grown for $16 \mathrm{~h}$ at $200 \mathrm{rpm}$ in $300 \mathrm{ml}$ TM in $500 \mathrm{ml}$ Erlenmeyer flasks. After $16 \mathrm{~h}, 10 \mathrm{~g}$ wet weight mycelium was harvested, washed with $0.9 \%$ $\mathrm{NaCl}$, and transferred to a 11 Erlenmeyer flask containing $150 \mathrm{ml} \mathrm{MM-X}$. The culture was shaken at $250 \mathrm{rpm}$ and $30{ }^{\circ} \mathrm{C}$ for $4 \mathrm{~h}$ (RNA sequencing) or $24 \mathrm{~h}$ (SDS-PAGE).

For growth on agar media, strains were inoculated directly on the medium or grown in a layer of $1.25 \%$ agarose in between two perforated polycarbonate membranes (pores of $0.1 \mu \mathrm{m}$, diameter $76 \mathrm{~mm}$; Profiltra, Almere, The Netherlands) (Wösten et al. 1991). These sandwiched cultures were inoculated in the center of the agarose layer by placing a $2 \mu \mathrm{l}$ drop containing $10^{4}$ conidia. The upper polycarbonate membrane was placed on top of the agarose layer $24 \mathrm{~h}$ after inoculation to prevent spreading of conidia. 
Inactivation and complementation constructs of fum 21

For the construction of the fum 21 deletion strain, $5^{\prime}$ and $3^{\prime}$ flanks of the gene were amplified from genomic DNA by PCR using primer pairs $1 / 2$ and $3 / 4$, respectively (Supplemental Table 1). The hygromycin resistance gene $h p h$ was amplified from vector pAN7.1 (Punt et al. 1987) using primer pair 5/6 (Supplemental Table 1). Split marker fragments of this selection marker were created by fusion PCR (Arenthorst et al. 2015) using primer pairs $1 / 7$ and $4 / 8$ (Supplemental Table 1) for the $5^{\prime}$ and $3^{\prime}$ fragment, respectively.

For the construction of the fum 21 complementation construct, the hygromycin resistance cassette contained in pAN7.1 was amplified using primers 9 and 10 (Supplemental Table 1) that contain XbaI sites at their $5^{\prime}$ ends. The amplified $3 \mathrm{~kb}$ fragment that had a shorter promoter and terminator region as compared to pAN7.1 was cloned in the XbaI site of pUC20, resulting in vector pWR11. Gene fum 21 with 1048 bp promoter and 444 bp terminator sequence was amplified from MA234.1 genomic DNA using Phusion polymerase (Thermo Fisher Scientific, Waltham, MA, USA) and primer pair 11/12 (Supplemental Table 1). The amplified fragment was inserted in the SmaI site of pWR11 by using the InFusion ${ }^{\circledR}$ HD Cloning Kit (Clontech, Mountain View, CA, USA). This resulted in vector $\mathrm{pDA} 1$ containing the hygromycin resistance cassette and gene fum 21 .

\section{Transformation of A. niger}

Transformation of A. niger was performed according to de Bekker et al. (2009). For inactivation of fum 21, the split marker fragments were transformed to strain MA234.1. Transformants were purified twice on MMXA containing hygromycin. Deletion of fum 21 was verified by Southern blot analysis using HindIII digested genomic DNA (Supplemental Fig. 1). For complementation, the disrupted kusA gene in the $\Delta$ fum 21 strain was first restored by selecting AmdS loop-out strains on $5^{\prime}$ fluoroacetamide (Carvalho et al. 2010) to facilitate ectopic integration. Since the fum 21 deletion strain was already hygromycin resistant, the resulting $\Delta$ fum $21 \mathrm{kusA}^{+}$strain was complemented by co-transforming vectors pDA1 and pMA357. The latter pJet1.2 (Thermo Fisher Scientific) based vector contains the amd $S$ gene and $3^{\prime}$ regulatory sequences of Aspergillus nidulans under control of the gpdA promoter. The amdS expression cassette (Meyer et al. 2007) was PCR amplified with primer pair 13/14 (Supplemental Table 1). Selection was done on $\mathrm{MM}$ containing $0.95 \mathrm{M}$ sucrose, $15 \mathrm{mM} \mathrm{CsCl}$, and $10 \mathrm{mM}$ acetamide as sole nitrogen source. Integration of the wild-type copy of the gene was confirmed by Southern blot analysis (Supplemental Fig. 1).

RNA sequencing and analysis

Mycelium of biological duplicates of liquid cultures pre-grown in TM and transferred to MM-X was frozen in liquid nitrogen and ground for $1 \mathrm{~min}$ at $25 \mathrm{~Hz}$ with a Tissue Lyzer II (Qiagen, Venlo, The Netherlands). Samples were taken up in $1 \mathrm{ml}$ TRIzol reagent (Invitrogen, Bleiswijk, The Netherlands) and incubated for $5 \mathrm{~min}$ at room temperature (RT). $0.2 \mathrm{ml}$ chloroform was added and samples were centrifuged for $15 \mathrm{~min}$ at $4{ }^{\circ} \mathrm{C}$ and $12,000 \times g$ after 2 min incubation at RT. Total RNA was precipitated from the resulting aqueous phase by addition of $0.5 \mathrm{ml}$ isopropanol, incubation at RT for $10 \mathrm{~min}$, and centrifugation for $10 \mathrm{~min}$ at $4{ }^{\circ} \mathrm{C}$ and $12,000 \times g$. RNA was washed with $1 \mathrm{ml} 75 \%$ ethanol, left to dry, and resuspended in RNAse-free water. RNA was purified using the NucleoSpin ${ }^{\circledR}$ RNA kit (Macherey-Nagel, Düren, Germany). Concentration and purity of RNA was checked using the Nanodrop ND-1000 (Thermo Fisher Scientific).

Library preparation, cluster generation, and sequencing of cDNA were performed by ServiceXS (Leiden, The Netherlands) using Illumina sequencing. The reads are deposited in NCBI GEO with accession number GSE93990. Tophat version 2.1.13 (Trapnell et al. 2009) was used to align sequence reads to the Aspni7 version of the A. niger ATCC 1015 genome (Andersen et al. 2011), which was obtained from Mycocosm (Grigoriev et al. 2014). Functional annotation of the predicted genes was described previously (Teertstra et al. 2017). Cuffdiff (version 2.2.1), which is part of Cufflinks (Trapnell et al. 2010), was used to identify reads mapping to predicted genes and to identify differentially expressed genes. The bias correction method was used while running Cuffdiff (Roberts et al. 2011). The expression level of each predicted gene was normalized to fragments per kilobase of exon model per million fragments 
(FPKM). In addition to Cuffdiff's requirements for differential expression the following requirements were applied: a $\geq 2$-fold change and a minimal expression level of 4 FPKM in at least one of the samples. The quality of these results was analyzed using CummeRbund (Goff et al. 2013).

\section{Q-PCR}

Expression of fum10 (proteinID 1117227), fums (ProteinID 1117230), and fuml (ProteinID 1162446) in A. niger wild type, $\Delta$ fum 21 , and 4 complemented strains was assessed by Q-PCR using beta-tubulin (ProteinID 208263) and 18S rRNA (GenBank sequence ID KC545869.1) as reference genes. Total RNA was isolated as described above from biological duplicates of CYA- and YES-grown sandwiched colonies, after which it was purified using NucleoSpin ${ }^{\circledR}$ RNA (Macherey-Nagel, Düren, Germany) and reverse transcribed using the QuantiTect Reverse Transcription Kit (Qiagen, Venlo, The Netherlands). The cDNA (1 ng) was used for SYBR Green Q-PCR using $200 \mathrm{nM}$ of the primer pairs 15/16 for fum10, (efficiency 98.7\%), 17/18 for fum8 (efficiency $104.4 \%$ ), 19/20 for fuml (efficiency 109.7\%), 21/22 for beta-tubulin (efficiency 102.1\%), and 23/24 for $18 \mathrm{~S}$ (efficiency 95.8\%) (Supplemental Table 1). No-template controls (NTCs) were included as a negative control and total reaction volumes were $10 \mu 1$. Samples were run on a ViiA ${ }^{\mathrm{TM}} 7$ Real-Time PCR System (Applied Biosystems, Wilmington DE, USA) and analyzed using the $\Delta \Delta \mathrm{Ct}$ method.

\section{SDS-PAGE}

Proteins in culture medium were precipitated overnight at $-20{ }^{\circ} \mathrm{C}$ after adding 4 volumes of acetone. They were pelleted twice for $30 \mathrm{~min}$ at $4{ }^{\circ} \mathrm{C}$ and $21,000 \times g$ with an intermediate washing step using $-20{ }^{\circ} \mathrm{C}$ acetone. After drying the pellets, sample buffer (125 mM Tris $\mathrm{pH} 6.8,4 \%$ sodium dodecyl sulfate (SDS), $17.4 \%$ glycerol, 5\% $\beta$-mercaptoethanol, $200 \mu \mathrm{g} / \mathrm{ml}$ bromophenol blue) was added resulting in a 20 -fold volume reduction when compared to the culture medium. Samples were incubated at $100{ }^{\circ} \mathrm{C}$ for $10 \mathrm{~min}$ and proteins were separated in $12.5 \%$ SDS-PAGE gels using Pierce ${ }^{\mathrm{TM}}$ Prestained Protein Molecular Weight Marker (Thermo Fisher Scientific) as reference. Gels were fixed with $50 \%$ methanol and $10 \%$ acetic acid for $10 \mathrm{~min}$, stained overnight with $0.1 \%$ Coomassie Brilliant Blue R-250, and destained with $25 \%$ methanol, $10 \%$ acetic acid. Gels were imaged using the Universal Hood III with Image Lab software (Bio-Rad Laboratories BV, Veenendaal, The Netherlands).

\section{Localization of protein secretion}

Protein secretion was monitored as described (Krijgsheld et al. 2013b) by labelling sandwiched colonies that had been grown on MM-XA for 6 days and transferred for $24 \mathrm{~h}$ to fresh MM-XA containing ${ }^{14} \mathrm{C}$ amino acids (NEC-850E amino acid mixture, L- $\left[{ }^{14} \mathrm{C}(\mathrm{U})\right]-$, Perkin Elmer, Waltham MA, USA).

\section{Protease activity}

A. niger was grown as a sandwiched colony (see above) on MM containing 33\% skimmed milk and $1.5 \%$ agar. After 5 days of growth, the sandwiched culture was removed and presence of halos monitored.

Secondary metabolite profiling

CYA and YES plates were inoculated in duplicate with $10^{4}$ conidia. After 7 days of growth at $25^{\circ} \mathrm{C}$, 56-mm wide mycelial plugs were taken along the diameter of the colony and freeze-dried. Secondary metabolites were extracted in duplicate from the plugs with ethylacetate/dichloromethane/methanol (3:2:1, $\mathrm{vol} / \mathrm{vol} / \mathrm{vol}$ ) with $1 \%$ formic acid using ultrasonic treatment for $50 \mathrm{~min}$ (Smedsgaard 1997). The extracts were transferred to a $2 \mathrm{ml}$ dram vial and taken up in $300 \mu \mathrm{l}$ methanol after removing the organic solvents by evaporation. Pyranonigrin A, pyranonigrin $\mathrm{X}$ (i.e. pyranonigrin B, C, D, E, or S), kotanin, BMS 192548 , aurasperone $\mathrm{B}$, tensidol $\mathrm{B}$, and funalenone were analyzed using ultra-high performance liquid chromatography (UHPLC) (Houbraken et al. 2012). These compounds were identified using diode array detection (UV spectra from 190-600 nm) with purified compounds as standard. The relative quantity of the metabolites was estimated based on absorption at $210 \mathrm{~nm}$ (milli absorption units, mAU). Fumonisin $\mathrm{B}_{2}$, $\mathrm{B}_{4}$, and $\mathrm{B}_{6}$ were quantified by UHPLC-High Resolution Mass Spectrometry (UHPLC-HRMS) using an Agilent Infinity 1290 UHPLC system (Agilent Technologies, Santa Clara, CA, USA) equipped with a 
diode array detector. Separation was obtained on an Agilent Poroshell 120 phenyl-hexyl column $(2.1 \times 250 \mathrm{~mm}, 2.7 \mu \mathrm{m})$ with a linear gradient consisting of water (A) and acetonitrile (B) both buffered with $20 \mathrm{mM}$ formic acid, starting at $10 \% \mathrm{~B}$, increased to $100 \% \mathrm{~B}$ in $15 \mathrm{~min}$, and held for $2 \mathrm{~min}$ at this composition, returned to $10 \% \mathrm{~B}$ in $0.1 \mathrm{~min}$ and held for $3 \mathrm{~min}$ at this composition $\left(0.35 \mathrm{ml} \mathrm{min}^{-1}, 60^{\circ} \mathrm{C}\right)$. An injection volume of $1 \mu \mathrm{l}$ was used. MS detection was performed on an Agilent 6540 QTOF MS equipped with Agilent Dual Jet Stream electrospray ion source with a drying gas temperature of $250{ }^{\circ} \mathrm{C}$, gas flow of $81 \mathrm{~min}^{-1}$, sheath gas temperature of $300{ }^{\circ} \mathrm{C}$ and flow of $121 \mathrm{~min}^{-1}$. Capillary and nozzle voltage were set at 4000 and $500 \mathrm{~V}$, respectively. Mass spectra were recorded at 10,20 , and $40 \mathrm{eV}$ as centroid data for $\mathrm{m} / \mathrm{z}$ 85-1700 in MS mode and $\mathrm{m} / \mathrm{z}$ 30-1700 in MS/MS mode, with an acquisition rate of $10 \mathrm{spectra} / \mathrm{s}$. Lock mass solution in 70:30 methanol: water was infused in the second sprayer using an extra LC pump at a flow of $15 \mu \mathrm{lmin}^{-1}$ using a 1:100 splitter. The solution contained $1 \mu \mathrm{M}$ tributylamine (Sigma-Aldrich) and $10 \mu \mathrm{M}$ Hexakis (2,2,3,3-tetrafluoropropoxy)phosphazene (Apollo Scientific Ltd., Cheshire, UK) as lock masses. The $[\mathrm{M}+\mathrm{H}]+$ ions $(\mathrm{m} / \mathrm{z} 186.2216$ and 922.0098 , respectively) of both compounds was used (Kildgaard et al. 2014; Klitgaard et al. 2014).

\section{Results}

Functional characterization of fum 21

Thirty eight predicted transcription factor genes are differentially expressed in xylose-grown colonies of $\triangle f b A$ when compared to wild type (Krijgsheld and Wösten 2013). Of these genes, An01g06900 (Cerqueira et al. 2014) is the most down-regulated predicted transcription factor gene with a 22,42 , and 31 fold-change in the central, middle, and the outermost concentric zone of the colony, respectively (Krijgsheld and Wösten 2013). This gene showed a bidirectional hit with the fumonisin regulator fum 21 of Fusarium (Proctor et al. 2013) showing 29\% identity at amino acid level and sharing the GAL4 DNA binding domain and the Middle Homology Region (MHR) domain (Supplemental Fig. 2). The fact that An01g06900 (i.e. fum21) is located in the predicted fumonisin gene cluster of $A$. niger (Supplemental Fig. 2) supports a role of this gene in fumonisin production.

Gene fum 21 was deleted in A. niger strain MA234.1, resulting in strain $\Delta$ fum 21 (Supplemental Fig. 1). Growth and conidiation were not affected in the deletion strain. Biomass of 7-day-old wild-type and $\Delta$ fum 21 sandwiched colonies was $17.20 \pm 3.4 \mathrm{mg}$ and $17.43 \pm 2.0 \mathrm{mg}( \pm \mathrm{SD}, n=7$, $p>0.05)$, while colony diameter was $4.6 \pm 0.63 \mathrm{~cm}$ and $4.9 \pm 0.29 \mathrm{~cm}( \pm \mathrm{SD}, n=6, p>0.05)$. Conidiation in the two strains took place in the sub-peripheral zone and the center of the colonies (Fig. 1a, b). These sporulation zones did not secrete proteins (Fig. 1c, d). SDS-PAGE protein profiles obtained in liquid cultures were not different between the strains (data not shown). Degradation of skimmed milk (data not shown) and the number of spores that were produced also did not differ (Fig. 1e). These data show that conidiation and sporulation-inhibited secretion are still functional in $\Delta$ fum 21 .

Strain $\Delta$ fum 21 and its progenitor were grown for 7 days on CYA. Fumonisin $\mathrm{B}_{2}, \mathrm{~B}_{4}$, and $\mathrm{B}_{6}$ could be extracted from mycelial plugs from different zones of wild-type colonies. In contrast, $\Delta$ fum 21 did not produce these metabolites (Fig. 2a). Similar results were obtained when colonies were grown on YES medium (data not shown). Production of pyranonigrin A was also reduced by $25 \%$ in the deletion strain but production of other secondary metabolites was not affected when $\Delta$ fum 21 and the wild type were grown on CYA (Fig. 2b) and YES (data not shown) medium.

Gene expression analysis

Gene expression in $\Delta f u m 21$ and the wild-type progenitor strain was assessed by RNA sequence analysis after growth in TM for $16 \mathrm{~h}$ followed by transfer to MM-X for $4 \mathrm{~h}$. This analysis revealed that only 74 genes were differentially expressed in $\Delta$ fum 21 relative to the wild type. Of these genes, 63 were downregulated and 11 were up-regulated in the deletion strain (Table 1; Supplemental Table 2). Of the upregulated genes, 7 have a predicted signal sequence for secretion including genes encoding lipases, a protease, a cellobiohydrolase and an anti-fungal protein. Of the down-regulated genes, 12 genes encode a protein without annotation and 24 genes are predicted to be involved in secondary metabolism. Of the latter genes, 
A
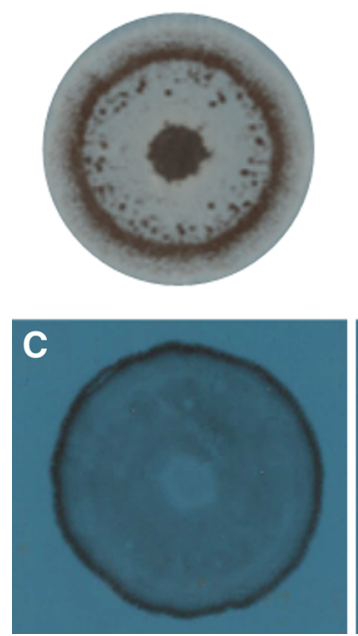

B
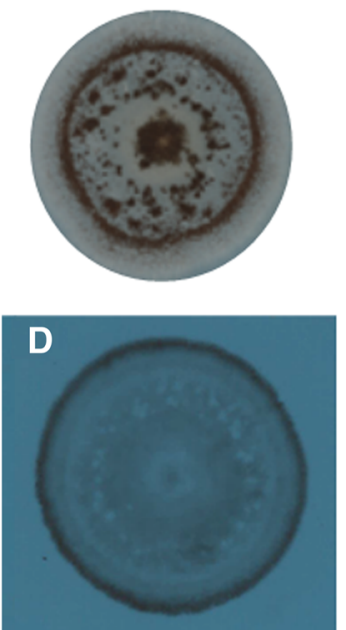

E

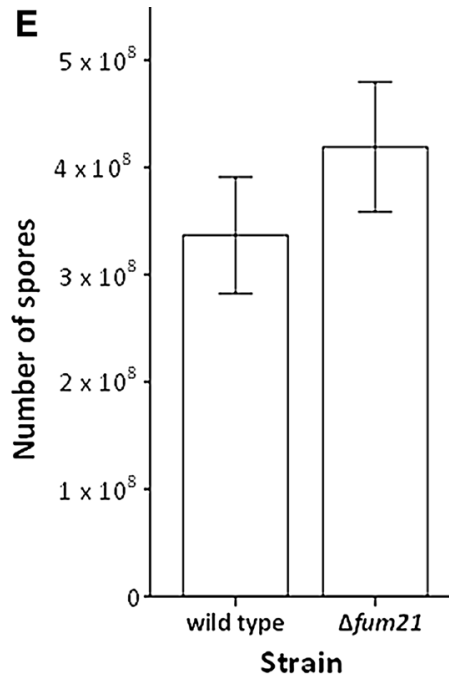

Fig. 1 Spatial distribution of sporulation (a, b), protein secretion $(\mathbf{c}, \mathbf{d})$, and the number of spores that were produced (e) in 8-day-old xylose-grown colonies of the wild-type strain MA234.1 (a, c) and $\Delta f u m 21(\mathbf{b}, \mathbf{d})$. Secretion was monitored by immobilizing ${ }^{14} \mathrm{C}$-labeled secreted proteins on a PVDF membrane that had been placed underneath the colony. Localization and quantification of sporulation was monitored $48 \mathrm{~h}$ after removal of the upper membrane of sandwiched colonies
20 are located in the secondary metabolism clusters 1 (3 out of 21 genes down-regulated), 12 (4 out of 13 genes down-regulated), 70 (3 out of 6 genes downregulated), and 15 (10 out of 12 genes downregulated). The secondary metabolites produced by the proteins encoded by clusters 1 and 12 are unknown but clusters 70 and 15 are predicted to be involved in TAN-1612 and fumonisin production, respectively ( $\mathrm{Li}$ et al. 2011; Khaldi and Wolfe 2011). The downregulated genes in the fumonisin cluster included fum10, fum 8 , and fum1 (Table 2), which are predicted to be involved in the early catalytic steps of fumonisin synthesis in Fusarium (Proctor et al. 2003). Q-PCR analysis showed that their expression was absent in $\Delta$ fum 21 of A. niger and restored in two complemented strains (data not shown).

Expression of the 74 differentially expressed genes in $\Delta$ fum 21 was assessed in the central, intermediate, and outer zones of wild-type and $\triangle f b A$ colonies using data of Krijgsheld and Wösten (2013). Six out of 11 up-regulated genes in $\Delta f u m 21$ were down-regulated in $\triangle f b A$ (Supplemental Table 3). Conversely, 10 out of the 63 down-regulated genes in $\Delta$ fum 21 were upregulated in $\triangle f b A$. In addition, 13 of the downregulated genes in $\Delta f u m 21$ were also down-regulated in $\triangle f b A$ among which all genes of the fumonisin cluster (Supplemental Table 4). The genes in the fumonisin cluster were highly expressed at the periphery of xylose-grown colonies of A. niger, 6 of which were statistically significantly more highly expressed (i.e. exhibited $>2$-fold higher expression levels) in this zone when compared to the more inner zones. Gene fum 21 was not differentially expressed in zones of the wild-type colonies.

\section{Discussion}

Most wild-type A. niger strains produce fumonisin in liquid and solid cultures (Frisvad et al. 2007, 2011). Fumonisins are potent mycotoxins that exhibit neurotoxicity, hepatotoxicity, and nephrotoxicity in various animal models. They have also been linked to tumor formation in humans (esophageal cancer) and animals (Stockmann-Juvala and Savolainen 2008). The fumonisin biosynthesis cluster of $A$. niger has been proposed to originate from a horizontal gene transfer event (Khaldi and Wolfe 2011). The Fusarium cluster consists of up to 17 genes depending on the species (Proctor et al. 2003, 2008; Brown et al. 2007; Wiemann et al. 2013). Of these genes, expression of at least fuml and fums is controlled by the 


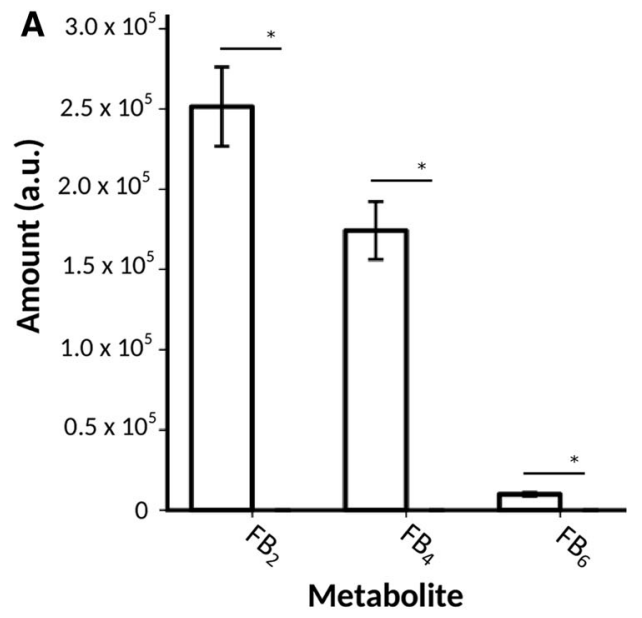

B

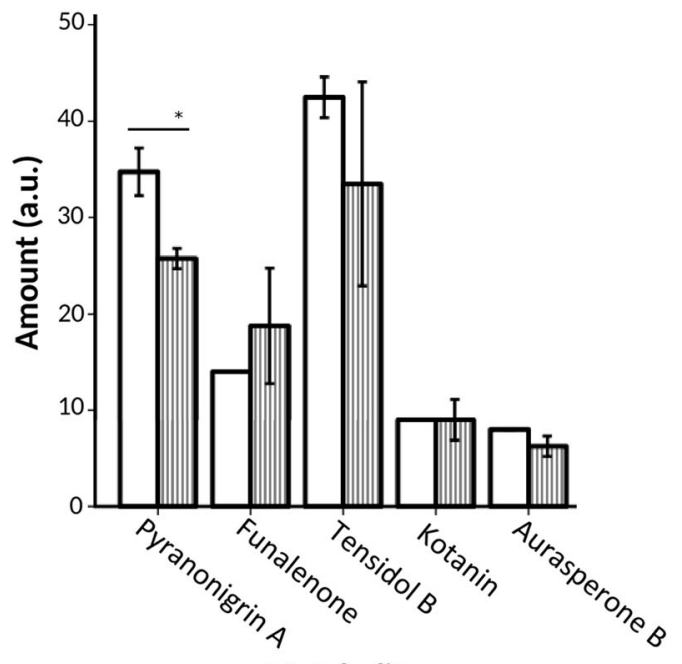

Metabolite

Fig. 2 Amount of fumonisin $\mathrm{B}_{2}, \mathrm{~B}_{4}$, and $\mathrm{B}_{6}\left(\mathrm{FB}_{2}, \mathrm{FB}_{4}\right.$, and $\mathrm{FB}_{6}$, respectively) (a) and other secondary metabolites (b) in arbitrary units (a.u.), produced by the wild-type strain MA234.1 (open bars) and $\Delta$ fum 21 (gray shaded bars) in CYA medium. Asterisk indicates significant differences $(p \leq 0.05)$ between the two strains indicated by the horizontal line below the asterisk

transcriptional regulator Fum21 (Brown et al. 2007). A bidirectional BLAST showed that gene An01g06900 of A. niger is the orthologue of fum 21 of Fusarium. Inactivation of fum 21 in A. niger did not impact vegetative growth, mycelium morphology, conidiation, and (spatial) secretion of proteins. In contrast, $\Delta$ fum 21 of $A$. niger did not produce fumonisin, while expression of 10 out of 12 genes of the fumonisin gene cluster was reduced. These data show that Fum21 controls fumonisin production as was previously shown in Fusarium (Brown et al. 2007).

The function of Fum21 of A. niger and Fusarium verticillioides is remarkably similar despite the evolutionary distance between these species that belong to the Sordariomycetes and the Eurotiomycetes, respectively. Both proteins activate fumonisin production, while not affecting other processes such as growth and sporulation (Brown et al. 2007). In addition, both fum 21 homologs are regulated by genes involved in asexual development; i.e. the VeA homolog FvVE1 in F. verticillioides (Myung et al. 2009) and $f b A$ in $A$. niger. It should be noted that deletion of fum 21 in $A$. niger completely abolished fumonisin production, while some fumonisin can still be detected in the fum 21 deletion strain of $F$. verticillioides. In the latter case the transcription factor genes pacl and zfrl also impact biosynthesis of this secondary metabolite (Shim and Woloshuk 2001; Flaherty et al. 2003; Flaherty and Woloshuk 2004; Bluhm and Woloshuk 2006). A. niger has orthologues of both genes. Future studies should confirm a role of these genes in fumonisin production. They might for instance regulate fum 15 and fum19 that were shown not to be regulated by fum 21 . Results also showed that Fum 21 of $A$. niger impacts production of the secondary metabolite pyranonigrin A. Indeed, absence of Fum 21 of $A$. niger affected expression of genes of three other secondary metabolite clusters. Whether Fum 21 of $F$. verticillioides also affects expression of other secondary metabolite clusters is not known.

As mentioned above, fum 21 is down-regulated in $\triangle f b A$ (Krijgsheld and Wösten 2013). This implies that FlbA is not only involved in conidiation, spatial secretion of proteins, composition of the secretome, cell wall architecture, and lysis of hyphae (Krijgsheld et al. 2013b) but also in controlling secondary metabolism. Indeed, all genes of the fumonisin cluster are down-regulated in $\triangle f b A$ (Krijgsheld and Wösten 2013). The fact that Fum 21 does not control expression of 2 out of 12 genes of the cluster implies that FlbA impacts expression of another transcription factor involved in fumonisin production. Of interest, the pacl homologue of $A$. niger (known as pacC) is upregulated in $\triangle f b A$ (Krijgsheld and Wösten 2013). Possibly, this transcription factor is a repressor of genes in this mycotoxin cluster.

LaeA was initially identified as a regulator of secondary metabolism in A. nidulans (Bok and Keller 
Table 1 Differentially expressed genes in liquid shaken cultures of $\Delta$ fum 21 and the wild-type strain (for full dataset, see Supplemental Table 2)

\begin{tabular}{|c|c|c|c|}
\hline Protein id & $\Delta$ fum21 & Wild type & Functional annotation \\
\hline \multicolumn{4}{|c|}{ Down-regulated genes in $\Delta$ fum 21} \\
\hline 1166045 & 0 & 13.21 & AAA + -type ATPase \\
\hline 1182124 & 0 & 4.89 & Major facilitator superfamily transporter \\
\hline 225717 & 0 & 29.92 & fum 21 \\
\hline 1117227 & 0.30 & 519.60 & Peroxisomal acyl-CoA synthetase; fum10 orthologue \\
\hline 1117230 & 0.25 & 368.97 & $\alpha$-Oxoamine synthase; serine palmitoyltransferase; fum 8 orthologue \\
\hline 1182116 & 0.39 & 573.20 & Fe-containing alcohol dehydrogenase type IV; fum7 orthologue \\
\hline 1142053 & 1.09 & 1433.24 & No annotation \\
\hline 1162446 & 0.25 & 167.04 & Polyketide synthase; fum 1 orthologue \\
\hline 1162442 & 2.19 & 913.32 & NAD-dependent epimerase/dehydratase; fum13 orthologue \\
\hline 1101614 & 0.98 & 236.55 & Cytochrome p450; fum6 orthologue \\
\hline 1142051 & 8.34 & 1607.79 & No annotation \\
\hline 1166044 & 2.75 & 347.93 & No annotation \\
\hline 1172265 & 1.62 & 191.62 & Oxidoreductase \\
\hline 1162443 & 6.66 & 564.86 & CoA-dependent acyltransferase; fum 14 orthologue \\
\hline 1186369 & 0.57 & 19.06 & $\mathrm{Ca}^{2+}$-modulated nonselective cation channel polycystin \\
\hline 51907 & 3.73 & 110.86 & Predicted 3-ketosphinganine reductase \\
\hline 1181633 & 0.49 & 12.69 & SWI-SNF chromatin-remodeling complex protein \\
\hline 1082505 & 1.48 & 32.99 & Major facilitator superfamily transporter \\
\hline 1142861 & 1.59 & 33.92 & Chloroperoxidase \\
\hline 1159889 & 0.93 & 17.88 & O-methyltransferase \\
\hline 1087288 & 2.37 & 39.12 & Taurine catabolism dioxygenase TauD \\
\hline 45784 & 1.70 & 25.17 & $\mathrm{Ca}^{2+}$-modulated nonselective cation channel polycystin \\
\hline 1169210 & 5.86 & 72.09 & Glutathione S-transferase-like protein \\
\hline 1116476 & 2.31 & 28.18 & CDR ABC transporter \\
\hline 1089440 & 2.52 & 29.10 & Major facillitator superfamily transporter \\
\hline 1112167 & 0.60 & 6.38 & Polyketide synthase AdaA \\
\hline 1181632 & 2.79 & 26.80 & No annotation \\
\hline 1115620 & 1.27 & 12.02 & C-type lectin \\
\hline 189113 & 8.60 & 80.47 & NmrA-like family protein \\
\hline 1005100 & 2.33 & 21.65 & No annotation \\
\hline 1186279 & 20.64 & 191.85 & No annotation \\
\hline 1103854 & 1.34 & 11.77 & Glycosyl transferase \\
\hline 1139199 & 4.02 & 34.97 & Mono-oxygenase, FAD-binding/aromatic ring hydroxylase \\
\hline 1186352 & 2.74 & 23.65 & Molecular chaperone \\
\hline 1109756 & 1.59 & 13.54 & Kinesin-related protein \\
\hline 1187549 & 1.99 & 16.75 & Integral membrane protein \\
\hline 1125454 & 0.71 & 5.80 & Dihydroxy-acid dehydratase \\
\hline 1184525 & 3.92 & 31.30 & Non-ribosomal peptide synthetase \\
\hline 1124090 & 2.40 & 18.02 & Tryptophan synthase \\
\hline 1015414 & 1.95 & 14.50 & Short chain dehygrogenase \\
\hline 1139200 & 33.67 & 239.67 & AdaD \\
\hline 1187587 & 2.19 & 15.55 & AAA+ -type ATPase \\
\hline 1152279 & 4.10 & 28.71 & Major facilitator superfamily transporter \\
\hline
\end{tabular}


Table 1 continued

\begin{tabular}{|c|c|c|c|}
\hline Protein id & $\Delta$ fum 21 & Wild type & Functional annotation \\
\hline 1162650 & 21.21 & 146.94 & Aegerolysin \\
\hline 1200239 & 5.00 & 34.01 & NmrA-like family protein \\
\hline 1223842 & 1.36 & 9.10 & hypothetical FAD/FMN-containing dehydrogenase \\
\hline 1186845 & 0.79 & 5.13 & No annotation \\
\hline 1187028 & 192.14 & 1228.87 & No annotation \\
\hline 1181350 & 3.78 & 21.89 & Aspergillus kawachii D-alanine-D-alanine ligase orthologue \\
\hline 1157348 & 5.074 & 28.54 & UDP-glucose 4-epimerase \\
\hline 1186355 & 2.26 & 12.65 & FAD-linked oxidase \\
\hline 1155959 & 6.55 & 34.31 & MNNG and nitrosoguanidine resistance protein \\
\hline 1141103 & 32.82 & 162.69 & trkA-N domain dehydrogenase \\
\hline 1107461 & 1.26 & 6.04 & Chitinase \\
\hline 1187643 & 9.17 & 43.25 & No annotation \\
\hline 1099871 & 4.00 & 18.48 & Flavin-containing monooxygenase \\
\hline 1124492 & 3.68 & 16.34 & Phosphoglycerate mutase \\
\hline 1135815 & 9.66 & 41.71 & Serine/threonine kinase \\
\hline 52063 & 18.67 & 80.01 & No annotation \\
\hline 1150465 & 11.56 & 48.79 & No annotation \\
\hline 1161325 & 56.49 & 217.67 & Integral membrane protein \\
\hline 1141963 & 25.56 & 92.48 & Glutathione S-transferase \\
\hline 1145979 & 10.39 & 35.46 & GMC oxidoreductase \\
\hline \multicolumn{4}{|c|}{ Up-regulated genes in $\Delta$ fum 21} \\
\hline 1184413 & 92.14 & 22.85 & Serine/threonine kinase \\
\hline 1184369 & 139.39 & 31.11 & Lipase \\
\hline 1156756 & 32.65 & 6.04 & No annotation \\
\hline 1185088 & 26.99 & 4.98 & No annotation \\
\hline 1180662 & 357.01 & 65.37 & Lipase \\
\hline 1181154 & 89.30 & 13.98 & No annotation \\
\hline 1183897 & 535.00 & 81.16 & Antifungal protein \\
\hline 1117716 & 35.428 & 5.03 & Glycoside hydrolase family 7 protein $\mathrm{CbhB}$ \\
\hline 1187764 & 19.37 & 2.5476 & No annotation \\
\hline 1146836 & 6.24 & 0.69 & Hypothetical FAD/FMN-containing dehydrogenase \\
\hline 1164071 & 108.91 & 11.66 & Peptidase G1, eqolisin \\
\hline
\end{tabular}

Both strains had been grown in TM for $16 \mathrm{~h}$ followed by $4 \mathrm{~h}$ in MM-X. Gene expression is expressed as Fragments Per Kilobase Of Exon Per Million Fragments Mapped (FPKM)

2004). It controls expression of several gene clusters, including clusters involved in production of sterigmatocystin, penicillin, and lovastatin. LaeA is also involved in secondary metabolism in A. niger. It does not impact fumonisin production but it represses production of the compounds BMS-192548 and aspernigrin $\mathrm{A}$, while activating production of asperrubrol, atromentin, and JBIR86 (Niu et al. 2015).
Experimental data showed that production of aurasperone B, funalenone, kotanin, and tensidol are neither regulated by Fum21 (this work) nor by LaeA (Niu et al. 2015). This implies that other regulatory genes are involved in the production of these secondary metabolites. The fact that expression of laeA is not affected by FlbA in $A$. niger implies that its regulation is different from that of fum 21 . Together, 
Table 2 Expression of the genes of the fumonisin cluster in liquid shaken cultures of $\Delta$ fum 21 and the wild-type strain

\begin{tabular}{|c|c|c|c|}
\hline \multirow[t]{2}{*}{ ProteinId } & \multirow{2}{*}{$\begin{array}{l}\text { Functional } \\
\text { annotation }\end{array}$} & \multicolumn{2}{|c|}{ Expression } \\
\hline & & $\Delta$ fum 21 & wild type \\
\hline 1101614 & fum6 & 0.98 & 236.55 \\
\hline 51907 & $s d r 1$ & 3.73 & 110.86 \\
\hline 1117227 & fum10 & 0.30 & 519.60 \\
\hline 1182116 & fum7 & 0.39 & 573.20 \\
\hline 1182117 & fum3* & 0.28 & 894.82 \\
\hline 1117230 & fum8 & 0.25 & 368.97 \\
\hline 1162442 & fum13 & 2.19 & 913.32 \\
\hline 1162443 & fum14 & 6.66 & 564.86 \\
\hline 225717 & fum 21 & 0 & 29.92 \\
\hline 1117235 & fum15* & 65.98 & 40.50 \\
\hline 1182122 & fum19* & 218.64 & 146.37 \\
\hline 1162446 & fum1 & 0.25 & 167.04 \\
\hline
\end{tabular}

Both strains had been grown in TM for $16 \mathrm{~h}$ followed by $4 \mathrm{~h}$ in MM-X. Gene expression is expressed as Fragments Per Kilobase Of Exon Per Million Fragments Mapped (FPKM). Gray shading indicates genes that are down-regulated in $\Delta$ fum 21 when compared to the wild-type strain. Asterisk indicates genes that are not significantly differentially expressed

these results indicate that fum 21 , laeA, and other transcriptional regulators are involved in secondary metabolite production in A. niger. These genes are potential targets to improve $A$. niger as a cell factory by minimizing production of mycotoxins.

Funding This study was funded by BE-BASIC under Flagship 10.

\section{Compliance with ethical standards}

Conflict of interest The authors declare that they have no conflict of interest.

Open Access This article is distributed under the terms of the Creative Commons Attribution 4.0 International License (http:// creativecommons.org/licenses/by/4.0/), which permits unrestricted use, distribution, and reproduction in any medium, provided you give appropriate credit to the original author(s) and the source, provide a link to the Creative Commons license, and indicate if changes were made.

\section{References}

Andersen MR, Salazar MP, Schaap PJ, van de Vondervoort PJ, Culley D, Thykaer J, Frisvad JC, Nielsen KF, Albang R, Albermann K, Berka RM, Braus GH, Braus-Stromeyer SA, Corrochano LM, Dai Z, van Dijck PW, Hofmann G, Lasure LL, Magnuson JK, Menke H, Meijer M, Meijer SL, Nielsen JB, Nielsen ML, van Ooyen AJ, Pel HJ, Poulsen L, Samson RA, Stam H, Tsang A, van den Brink JM, Atkins A, Aerts A, Shapiro H, Pangilinan J, Salamov A, Lou Y, Lindquist E, Lucas S, Grimwood J, Grigoriev IV, Kubicek CP, Martinez D, van Peij NN, Roubos JA, Nielsen J, Baker SE (2011) Comparative genomics of citric-acid-producing 
Aspergillus niger ATCC 1015 versus enzyme-producing CBS 513.88. Genome Res 21:885-897

Arenthorst M, Jing N, Ram AFJ (2015) Efficient generation of Aspergillus niger knock out strains by combining NHEJ mutants and a split Marker Approach. In: van den Berg MA, Maruthachalam K (eds) Genetic transformation systems in fungi, vol 1. Springer, Basel, pp 263-272

Bluhm BH, Woloshuk CP (2006) Fck1, a C-type cyclin-dependent kinase, interacts with Fcc1 to regulate development and secondary metabolism in Fusarium verticillioides. Fungal Genet Biol 43:146-154

Bok JW, Keller NP (2004) LaeA, a regulator of secondary metabolism in Aspergillus spp. Eukaryot Cell 3:527-535

Brown DW, Butchko RAE, Busman M, Proctor RH (2007) The Fusarium verticillioides FUM gene cluster encodes a $\mathrm{Zn}$ (II)2Cys6 protein that affects FUM gene expression and fumonisin production. Eukaryot Cell 6:1210-1218

Carvalho ND, Arentshorst M, Jin Kwon M, Meyer V, Ram AFJ (2010) Expanding the $k u 70$ toolbox for filamentous fungi: establishment of complementation vectors and recipient strains for advanced gene analyses. Appl Microbiol Biotechnol 87:1463-1473

Cerqueira GC, Arnaud MB, Inglis DO, Skrzypek MS, Binkley G, Simison M, Miyasato SR, Binkley J, Orvis J, Shah P, Wymore F, Sherlock G, Wortman JR (2014) The Aspergillus Genome Database: multispecies curation and incorporation of RNA-Seq data to improve structural gene annotations. Nucl Acids Res 42:D705-D710

de Bekker C, Wiebenga A, Aguilar G, Wösten HAB (2009) An enzyme cocktail for efficient protoplast formation in Aspergillus niger. J Microbiol Methods 76:305-306

de Vries RP, Burgers K, van de Vondervoort PJ, Frisvad JC, Samsom RA, Visser J (2004) A new black Aspergillus species, A. vadensis, is a promising host for homologous and heterologous protein production. Appl Environ Microbiol 70:3954-3959

Flaherty JE, Woloshuk CP (2004) Regulation of fumonisin biosynthesis in Fusarium verticillioides by a zinc binuclear cluster-type gene ZFR1. Appl Environ Microbiol 70:2653-2659

Flaherty JE, Pirttila AM, Bluhm BH, Woloshuk CP (2003) $\mathrm{PAC1}$, a pH-regulatory gene from Fusarium verticillioides. Appl Environ Microbiol 69:5222-5227

Frisvad JC, Samson RA (2004) Polyphasic taxonomy of Penicillium subgenus Penicillium. A guide to identification of the food and air-borne terverticillate Penicillia and their mycotoxins. Stud Mycol 49:1-173

Frisvad JC, Smedsgaard J, Samson RA, Larsen TO, Thrane U (2007) Fumonisin B2 production by Aspergillus niger. J Agric Food Chem 55:9727-9732

Frisvad JC, Larsen TO, Thrane U, Meijer M, Varga J, Samson RA, Nielsen KF (2011) Fumonisin and ochratoxin production in industrial Aspergillus niger strains. PLoS ONE 6:e23496

Goff L, Trapnell C, Kelley D (2013) CummeRbund: analysis, exploration, manipulation, and visualization of Cufflinks high-throughput sequencing data. $\mathrm{R}$ package version 2.16.0

Grigoriev IV, Nikitin R, Haridas S, Kuo A, Ohm R, Otillar R, Riley R, Salamov A, Zhao X, Korzeniewski F, Smirnova T, Nordberg H, Dubchak I, Shabalov I (2014) MycoCosm portal: gearing up for 1000 fungal genomes. Nucleic Acids Res 42:D699-D704

Houbraken J, Spierenburg H, Frisvad JC (2012) Rasamsonia, a new genus for thermotolerant and thermophilic Talaromyces and Geosmithia species. Antonie van Leeuwenhoek J Gen Microbiol 101:403-421

Khaldi N, Wolfe KH (2011) Evolutionary origins of the fumonisin secondary metabolite gene cluster in Fusarium verticillioides and Aspergillus niger. Int $\mathrm{J}$ Evolut Biol. doi:10.4061/2011/423821

Kildgaard S, Mansson M, Dosen I, Klitgaard A, Frisvad JC, Larsen TO, Nielsen KF (2014) Accurate dereplication of bioactive secondary metabolites from marine-derived fungi by UHPLC-DAD-QTOFMS and MS/HRMS library. Marine Drugs 12:3681-3705

Klitgaard A, Iversen A, Andersen MR, Larsen TO, Frisvad JC, Nielsen KF (2014) Aggressive dereplication using UHPLC-DAD-QTOF - screening extracts for up to 3000 fungal secondary metabolites. Anal Bioanal Chem 406:1933-1943

Krijgsheld P, Wösten HAB (2013) Transcriptome analysis of zones of colonies of the $\triangle f b A$ strain of Aspergillus niger. Fungal Genomics Biol 3:1000109

Krijgsheld P, Bleichrodt R, van Veluw GJ, Wang F, Müller WH, Dijksterhuis J, Wösten HAB (2013a) Development in Aspergillus. Stud Mycol 74:1-29

Krijgsheld P, Nitsche BM, Post H, Levin AM, Müller WH, Heck AJR, Ram AFJ, Altelaar AFM, Wösten HAB (2013b) Deletion of $f l b A$ results in increased secretome complexity and reduced secretion heterogeneity in colonies of Aspergillus niger. J Prot Res 12:1808-1819

Kusters-van Someren MA, Harmsen JA, Kester HC, Visser J (1991) Structure of the Aspergillus niger pelA gene and its expression in Aspergillus niger and Aspergillus nidulans. Curr Genet 20:293-299

Li Y, Chooi YH, Sheng Y, Valentine JS, Tang Y (2011) Comparative characterization of fungal anthracenone and naphthacenedione biosynthetic pathways reveals an $\alpha$-hydroxylation-dependent Claisen-like cyclization catalyzed by a dimanganese thioesterase. J Am Chem Soc 133:15773-15785

Meyer V, Arentshorst M, El-Ghezal A, Drews AC, Kooistra R, van den Hondel CA, Ram AF (2007) Highly efficient gene targeting in the Aspergillus niger kusA mutant. J Biotechnol 128:770-775

Meyer V, Wu B, Ram AFJ (2011) Aspergillus as a multi-purpose cell factory: current status and perspectives. Biotechnol Lett 33:469-476

Myung K, Li S, Butchko RA, Busman M, Proctor RH, Abbas HK, Calvo AM (2009) FvVE1 regulates biosynthesis of the mycotoxins fumonisins and fusarins in Fusarium verticillioides. J Agric Food Chem 57:5089-5094

Niu J, Arentshorst M, Nair PD, Dai Z, Baker SE, Frisvad JC, Nielsen KF, Punt PJ, Ram AFJ (2015) Identification of a classical mutant in the industrial host Aspergillus niger by systems genetics: LaeA is required for citric acid production and regulates the formation of some secondary metabolites. G3 6(1):193-204

Park J, Hulsman M, Arentshorst M, Breeman M, Alazi E, Lagendijk EL, Rocha MC, Malavazi I, Nitsche BM, van den Hondel CA, Meyer V, Ram AFJ (2016) Transcriptomic 
and molecular genetic analysis of the cell wall salvage response of Aspergillus niger to the absence of galactofuranose synthesis. Cell Microbiol 18:1268-1284

Proctor RH, Brown DW, Plattner RD, Desjardins AE (2003) Coexpression of 15 contiguous genes delineates a fumonisin biosynthetic gene cluster in Gibberella moniliformis. Fungal Genet Biol 38:237-249

Proctor RH, Busman M, Seo JA, Lee YW, Plattner RD (2008) A fumonisin biosynthetic gene cluster in Fusarium oxysporum strain O-1890 and the genetic basis for B versus C fumonisin production. Fungal Genet Biol 45:1016-1026

Proctor RH, Van Hove F, Susca A, Stea G, Busman M, van der Lee T, Waalwijk C, Moretti A, Ward TJ (2013) Birth, death and horizontal transfer of the fumonisin biosynthetic gene cluster during the evolutionary diversification of Fusarium. Mol Microbiol 90:290-306

Punt PJ, Oliver RP, Dingemanse MA, Pouwels PH, Van den Hondel CA (1987) Transformation of Aspergillus based on the hygromycin B resistance marker from Escherichia coli. Gene 56:117-124

Roberts A, Trapnell C, Donaghey J, Rinn JL, Pachter L (2011) Improving RNA-Seq expression estimates by correcting for fragment bias. Genome Biol 12:R22

Samson RA, Visagie CM, Houbraken J, Hong S-B, Hubka V, Klaassen CHW, Perrone G, Seifert KA, Susca A, Tanney JB, Varga J, Kocsubé S, Szigeti G, Yaguchi T, Frisvad JC (2014) Phylogeny, identification and nomenclature of the genus Aspergillus. Stud Mycol 78:141-173

Shim WB, Woloshuk CP (2001) Regulation of fumonisin $\mathrm{B} 1$ biosynthesis and conidiation in Fusarium verticillioides by a cyclin-like (C-type) gene, FCC1. Appl Environ Microbiol 67:1607-1612

Smedsgaard J (1997) Micro-scale extraction procedure for standardized screening of fungal metabolite production in cultures. J Chromatogr A 760:264-270

Stockmann-Juvala H, Savolainen K (2008) A review of the toxic effects and mechanisms of action of fumonisin B1. Hum Exp Toxicol 27:799-809
Teertstra WR, Tegelaar M, Dijksterhuis J, Golovina EA, Ohm RA, Wösten HAB (2017) Maturation of conidia on conidiophores of Aspergillus niger. Fungal Genet Biol 98:61-70

Trapnell C, Pachter L, Salzberg SL (2009) TopHat: discovering splice junctions with RNA-Seq. Bioinformatics 25:1105-1111

Trapnell C, Williams BA, Pertea G, Mortazavi A, Kwan G, van Baren MJ, Salzberg SL, Wold BJ, Pachter L (2010) Transcript assembly and quantification by RNA-Seq reveals unannotated transcripts and isoform switching during cell differentiation. Nat Biotechnol 28:511-515

Wiemann P, Sieber CM, von Bargen KW, Studt L, Niehaus EM, Espino JJ, Huß K, Michielse CB, Albermann S, Wagner D, Bergner SV, Connolly LR, Fischer A, Reuter G, Kleigrewe K, Bald T, Wingfield BD, Ophir R, Freeman S, Hippler M, Smith KM, Brown DW, Proctor RH, Münsterkötter M, Freitag M, Humpf HU, Güldener U, Tudzynski B (2013) Deciphering the cryptic genome: genome-wide analyses of the rice pathogen Fusarium fujikuroi reveal complex regulation of secondary metabolism and novel metabolites. PLoS Pathog 6:e1003475

Wieser J, Lee BN, Fondon JW III, Adams TH (1994) Genetic requirements for initiating asexual development in Aspergillus nidulans. Curr Genet 27:62-69

Wösten HAB, Moukha SM, Sietsma JH, Wessels JGH (1991) Localization of growth and secretion of proteins in Aspergillus niger. J Gen Microbiol 137:2017-2023

Wösten HAB, van Veluw GJ, de Bekker C, Krijgsheld P (2013) Heterogeneity in the mycelium: implications for the use of fungi as cell factories. Biotechnol Lett 35:1155-1164

Yu J-H, Wieser J, Adams TH (1996) The Aspergillus FlbA RGS domain protein antagonizes $G$ protein signaling to block proliferation and allow development. EMBO J $15: 5184-5190$ 